This article is originally published in: J. Kauko (Regional Editor), W. J. Jacob and W. Xiong (Editors in Chief), Bloomsbury Education and Childhood Studies. London: Bloomsbury Academic.

\title{
Professional Development in Higher Education (Finland)
}

by Johanna Annala, Jyri Lindén, Petri Nokelainen, Terhi Skaniakos and Harri Kukkonen, DOI:10.5040/9781350996298.0029

\section{Professional development offerings}

Continuing professional development (CPD) refers to "the practices aimed at employees' development beyond that derived from their initial training" (Collin, Van der Heijden, and Lewis 2012: 155). In Finnish higher education (HE) most systematic and structured CPDs have typically focused on supporting individual teaching and learning-related competencies. In Finland, as in many countries, some areas of professionalism, such as management and leadership competencies, wider academic skills, or ethical dimensions, seem to be neglected, even as the academic professionalism and practice have changed (e.g., Daniels 2017; Nicholls 2001; Nixon 2008).

The parallel sectors of Finnish $\mathrm{HE}$, universities and universities of applied sciences (UAS), have different requirements for initial competencies and, consequently, a different approach for CPD (Eurydice 2018a). UAS identify staff members first and foremost as teachers and hands-on experts. To get a permanent position as a lecturer, a master's degree, three years of work experience, and a teacher's pedagogical qualification (60 European Credit Transfer and Accumulation System [ECTS]) are required. In order to proceed from lecturer to principal lecturer, a licentiate or doctoral degree is required (Finnish National Agency for Education [FNAE] 2018).

Universities follow the European four-stage career structure: doctoral, postdoctoral, independent researcher, and established researcher (Siekkinen, Pekkola, and Kivistö 2016). Even though almost all positions include teaching, the focus in achieving a certain career level is based on scientific merits. For formal pedagogical education, universities typically recommend or require pedagogical studies (10 ECTS).

\section{Strategic initiatives}

Through strategic funding related to CPD, the government focus is on the development of teaching and digitalization. In 2017, funding totalling 40 million euros was granted to nineteen HE development projects, to purposes such as strengthening digital learning environments, flexible studying, HE pedagogy, the operational cultures of HEls, cooperation between HEls and the workforce, and developing open RDI activities in institutions (Ministry of Education and Culture [MINEDU] n.d.). In 2017 to 2019, key projects focusing specifically on the development of HE teachers' pedagogical and digital competences include UNIPS (n.d.) at eight universities, flipped learning (n.d.) at four universities, and KOPE (n.d.) at one university and five UAS. 
The legislation appoints the universities to ensure a high standard in education and research (Universities Act 2009), and this has sometimes been interpreted as a reference to the need for systematic CPD (e.g., Eurydice 2018a). There are, however, no straight state-level financial incentives to develop a model for CPD. The upcoming changes in the Universities Act include a strategic goal to increase opportunities for continuous learning, which may encourage institutions to refresh their CPD policies (Government bill 2018). Besides, following the Standards and Guidelines for Quality Assurance in European Higher Education Area (ESG), the Finnish Education Evaluation Centre's (FINEEC) next audit model (2018-2024) includes criteria to assess how the HE quality system is used in the development of HE staff competence (FINEEC 2017).

\section{Technology}

The high data transfer capacity of national networks and up-to-date personal computers and smart devices (European Commission 2018) have enabled early adoption of Internet technologies (e.g., social media tools), digital learning platforms (e.g., Moodle), and online library services for HE professionals. Along with the basic infrastructure, different communication platforms (e.g., Skype, Adobe Connect, Zoom) and cooperation tools (e.g., Flinga, Padlet) are often introduced in pedagogical training or as part of everyday communication practices (e.g., in multi-campus universities).

Digital technologies are used to serve the needs of both formal and informal CPD; the aim is to use digital platforms with meaningful and flexible learning processes to encourage and ease digital participation at all career stages. For example, HowUTeach is a digital self-reflection tool (Unihow n.d.) in which the teacher provides self-assessment information on his/her approaches to teaching, level of self-efficacy, and coping strategies. The system responds with constructive feedback based on existing pedagogical research (e.g., Postareff, Mattsson and Parpala 2018).

\section{Types of faculty training}

The public web pages of Finnish HEls give little information about CPD offerings. Different sectors of support for CPD are divided among parts of the organization or into specialized networks. Most commonly, the institution's HR department takes care of the short training or mentoring regarding, for example, management and leadership, and work counselling. The ICT support unit organizes support for technology-related teaching and research platforms. In addition, library services offer training and support for information skills. Support activities are typically one- or two-day courses, workshops, or mentoring programs. Participation is usually voluntary and, in most cases, based on an individual's personal interests.

The pedagogically oriented CPD in universities focuses on developing individual pedagogical skills in formal, often credited courses. These courses are typically organized by teams closely related to the faculties of education. It is possible to complete teacher's pedagogical studies (60 ECTS) at schools of vocational teacher education in five UAS and at the five universities with faculties of education. In other universities, formal training is organized by staff support services or acquired from another university.

\section{Challenges in providing development opportunities}


Career progress is largely based on merits in research qualification or on teaching and learning related competencies (Siekkinen, Pekkola, and Kivistö 2016), but a shared qualification system based on progress in CPD activities does not exist. The lack of clarity for CPD criteria may discourage academics from engaging in longer or broader CPD programs.

HEls initiatives have focused on developing efficiency in research and producing graduates for working life since these have a strong relation to funding (Seuri and Vartiainen 2018). However, research skills (e.g., applying for funding or leadership in research) are often not considered a systematic part of CPD but more typically are based on an individual's activity to look for support. In UAS, where most teachers already have a pedagogical qualification, applied research and innovation are emphasized, creating a growing need for researcher competences. Yet there are no systematic initiatives to develop this area in CPD.

In tenure-track positions in universities, where CPD related competences are usually evaluated systematically, different faculties may have different evaluation criteria. For example, teaching portfolios are widely used, but teaching experience may be as much valued as formal pedagogical training. Gender seems to be an issue here too: (masculine) research is more valued for career development than (feminine) teaching merits (Jauhiainen 2014). When struggling with decreasing time and resources, academics often feel that the time spent on CPDs, especially when connected to teaching and learning, takes time directly away from research and career advancement.

Aalto University has found one solution; parallel to more traditional tenures, they implemented a systematic career path for lecturers where CPD pedagogical activities and formal training are considered merits. The University of Helsinki has a network of pedagogically oriented academics called the Teachers Academy (TA 2018). Peer-reviewed membership of the TA is based on highly competitive pedagogical qualities, and membership is considered a reward for teaching merits.

The remaining question is why academics may feel that research-related competencies can be developed by doing research, while other areas of academic practice, such as teaching, leadership, or ICT skills, often need formal training. This is one of the key challenges in CPD because it contributes to a separation between teaching and research. One step forward in Finland, and probably elsewhere, could be to rethink academic professionalism and try to see it as a starting point in a more holistic approach to professional development (Nicholls 2001).

\section{Evolving challenges in HE professional development}

During the last ten years, core funding of HEls has diminished and the role of competitive funding has increased. Expectations for greater efficiency have increased, along with the implementation of more controlled governing instruments accompanied by new administrative duties for faculty members (Tapanila, Siivonen, and Frilander 2018). Many HEls have undergone serious budget cuts and some employees have been laid off. In consequence, the remaining staff members have had to expand and develop their expertise in new areas. The CPD can thus be harnessed into the service and apparatus of increasing effectiveness and supporting management strategies. However, for the individual, academic development is fundamentally about holistically building identity and agency, becoming a reflective practitioner, and enhancing the research and teaching connection (Jauhiainen, Jauhiainen and Laiho 2009; Åkerlind 2011; Korhonen and Törmä 2016).

Additionally, short-term contracts at universities have been discussed as has the status of project researchers and international staff, who compose a noteworthy part in faculties (Puhakka 2016; Vipunen 2017). They seem to have fewer opportunities to join the CPD programs and other 
strategically important initiatives (Siekkinen, Pekkola, and Kivistö 2016). Also, when not having a tenure-track position, mid-career staff may fall into a gap between their professional goals and CPD needs (Juusola et al. 2018). Besides, in the situation where the CPD initiatives are mostly supported through projects, continuity may not be guaranteed.

When supporting CPD for HE staff, it is important to recognize the difference between strategically operated institutional CPD models and models and structures that emphasize the agency of individual scholars and academic communities (Clegg 2003), which is a precondition for autonomy and a fundamental factor for universities to exist and for professionals to flourish (Himanka 2018). Thus, the main challenges are how to advance CPD in relation to the two different perspectives, institutional and individual, and finding ways to holistically foster the necessary research-teaching interrelation.

\section{Further reading and online resources}

Eurydice. 2018. "Finland Overview: Key Features of the Education System." Accessed November 30, 2018. https://eacea.ec.europa.eu/national-policies/eurydice/content/finland_en.

Ministry of Education and Culture (MINEDU). n.d. "Development of Higher Education." Accessed November 30, 2018. https://minedu.fi/en/development-of-higher-education.

Pekkola, E., T. Carvalho, T. Siekkinen, and J.-E. Johanson 2018. "The Sociology of Professions and the Study of Academic Profession." In Theoretical and Methodological Perspectives on Higher Education Management and Transformation: An Advanced Reader for PhD Students, edited by E. Pekkola, J. Kivistö, V. Kohtamäki, Y. Cai, and A. Lyytinen, 121-150. Tampere: Tampere University Press.

Siekkinen, T., K. Kuoppala, E. Pekkola, and J. Välimaa. 2016. " "Reciprocal Commitment in Academic Careers? Finnish Implications and International Trends". "European Journal of Higher Education 7 (2): 120-135. doi: 10.1080/21568235.2016.1248990.

Vipunen. n.d. "Vipunen - Education Statistics Finland." Accessed November 30, 2018. https://vipunen.fi/en-gl/.

\section{References}

Åkerlind, G. S. 2011. " "Separating the 'Teaching' from the 'Academic': Possible Unintended Consequences"." Teaching in Higher Education 16 (2): 183-195. doi:

10.1080/13562517.2010.507310.

Clegg, S. 2003. "“Problematising Ourselves: Continuing Professional Development in Higher Education"." International Journal for Academic Development 8 (1-2): 37-50.

Collin, K., B. van der Heijden, and P. Lewis. 2012. " "Continuing Professional Development"." International Journal of Training and Development 16 (3): 155-163. doi: 10.1111/j.1468-

2419.2012.00410.x.

Daniels, J. 2017. " "Professional Learning in Higher Education: Making Good Practice Relevant"." International Journal for Academic Development 22 (2): 170-181. doi:

10.1080/1360144X.2016.1261352. 
European Commission (EC). 2018. "Human Capital: Digital Inclusion and Skills." In Digital Economy and Society Index Report 2018. Brussels: European Commission. Accessed November 30, 2018. https://ec.europa.eu/digital-single-market/en/desi.

Eurydice. 2018a. "Continuing Professional Development for Academic Staff Working in Higher Education. Finland." Accessed November 30, 2018. https://eacea.ec.europa.eu/nationalpolicies/eurydice/content/continuing-professional-development-academic-staff-working-highereducation-23_en.

Eurydice. 2018b. "Initial Education for Academic Staff in Higher Education, Finland." Accessed November 30, 2018. https://eacea.ec.europa.eu/national-policies/eurydice/content/initialeducation-academic-staff-higher-education-23_en.

Finnish Education Evaluation Centre (FINEEC). n.d. "Home." Accessed August 15, 2019. https://karvi.fi/en/.

Finnish Education Evaluation Centre (FINEEC). 2017. "Audit Manual of Higher Education Institutions 2018-2024." Finnish Education Evaluation Centre Publications 21. Accessed August 26, 2019. https://karvi.fi/en/higher-education/audits-higher-education-institutions-2018-2024/.

Finnish National Agency for Education (FNAE). 2018. "Teacher Education." Accessed November 30, 2018. https://www.oph.fi/english/education_system/teacher_education.

Flipped Learning Project. n.d. "Flipped Learning Project." Accessed November 30, 2018. https://www.uef.fi/en/web/ameba/flipped-learning.

Government bill. 2018. Hallituksen esitys eduskunnalle laeiksi yliopistolain ja ammattikorkeakoululain muuttamisesta [Bill on New Universities Act]. HE 152/2018. Accessed January 10, 2019. https://valtioneuvosto.fi/paatokset/paatos?decisionld=0900908f805db2e5.

Himanka, J. 2018. Korkein opetus, Opettamisen lähtökohdat yliopistoissa ja korkeakouluissa: johdatus opettajalle [The Highest Teaching]. Tampere: Vastapaino.

Jauhiainen, A. 2014. "Feministinen pedagogiikka uusliberalistisessa yliopistossa" [Feminist Pedagogy in Neoliberal University]. In Eroja ja vaarallisia suhteita. Keskustelua feministisestä pedagogiikasta [Differences and Dangerous Relations. Discussions about Feminist Pedagogy], edited by J. Saarinen, H. Ojala, and T. Palmu, 68-87. Jyväskylä: FERA.

Jauhiainen, A., A. Jauhiainen, and A. Laiho. 2009. "'The Dilemmas of the 'Efficiency University' Policy and the Everyday Life of University Teachers"." Teaching in Higher Education 14 (4): 417-428.

Juusola, H., J. Pakkasvirta, H. Peltonen, K. Saarikangas, M. Saikku, L. Tarkka, and M. Vainio. 2018. " "Urapolun ongelmat suomalaisissa yliopistoissa" [Problems with Tenure-Track in Finnish Universities]". Tieteessä tapahtuu 6: 61-63.

Korhonen, V. and S. Törmä. 2016. " "Engagement with a Teaching Career - How a Group of Finnish University Teachers Experience Teacher Identity and Professional Growth"." Journal of Further and Higher Education 40 (1): 65-82. doi: 10.1080/0309877X.2014.895301.

KOPE. n.d. "KOPE - Korkeakoulupedagogiikkaa yhteistyössä" [Collaboration in Higher Education Pedagogy]. Accessed November 30, 2018. https://www.oamk.fi/fi/tutkimus-jakehitys/hankkeet/kope/.

Ministry of Education and Culture (MINEDU). n.d. "Development of Higher Education." Accessed November 30, 2018. https://minedu.fi/en/development-of-higher-education. 
Nicholls, G. 2001. Professional Development in Higher Education: New Dimensions and Directions. London: Kogan Page.

Nixon, J. 2008. Towards the Virtuous University: The Moral Bases of Academic Practice. New York: Routledge.

Postareff, L. K., M. T. Mattsson, and A. M. Parpala. 2018. "The Effect of Perceptions of the Teaching-Learning Environment on the Variation in Approaches to Learning - Between-Student Differences and Within-Student Variation"." Learning and Individual Differences 68: 96-107.

Puhakka, A. 2016. Doctoral Candidates and Junior Researchers in 2016 Membership Survey of the Finnish Union of University Researchers and Teachers. Accessed November 30, 2018. https://tieteentekijoidenliitto.fi/files/2598/fuurt_survey.pdf.

Seuri, A. and H. Vartiainen. 2018. Yliopistojen rahoitus, kannustimet ja rakennekehitys 1 [Performance-based Funding and Structural Development in Universities]. Talouspolitikan arviointineuvoston taustaraportti [Report, Economic Policy Council], January 2018. Accessed January 11, 2019. https://www.talouspolitiikanarviointineuvosto.fi/raportit/raportti-2017/.

Siekkinen, T., E. Pekkola, and J. Kivistö. 2016. " "Recruitments in Finnish Universities: Practicing Strategic or Pathetic HRM?"" Nordic Journal of Studies in Educational Policy 2-3: 32316. doi:10.3402/nstep.v2.32316.

Universities Act. 2009. 558/2009. Accessed January 10, 2019. https://www.finlex.fi/en/laki/kaannokset/2009/en20090558.

Tapanila, K., P. Siivonen, and K. Filander. 2018. " "Academics' Social Positioning towards the Restructured Management System in Finnish Universities"." Studies in Higher Education, published online ahead of print November 1, 2018. doi: 10.1080/03075079.2018.1539957.

Teacher's Academy (TA). 2018. "Teacher's Academy. A Network of Top Teachers." Accessed November 30, 2018. https://www.helsinki.fi/en/university/teachers-academy.

UniHow. n.d. "Raising Awareness of What is Quality in Learning and Teaching." Accessed November 30, 2018. https://unihow.fi/.

UNIPS-project. n.d. "University Pedagogical Support." Accessed November 30, 2018. https://unips.fi/.

Vipunen. 2017. "Education Statistics Finland." Accessed November 30, 2018. https://vipunen.fi/en$\mathrm{gb} /$.

\section{Glossary terms}

\section{European Credit Transfer and Accumulation System (ECTS)}

ECTS credits represent the workload and defined learning outcomes of a given course or program. One credit is equivalent to student's work load of twenty-seven hours. Sixty credits are the equivalent of a full year of study or work. The system was designed to make it easier for students to move between different countries and universities in Europe.

\section{Finnish Education Evaluation Centre (FINEEC)}

An independent agency responsible for the national evaluation of education. The evaluations of FINEEC cover the education system from early childhood education to higher education (FINEEC n.d.).

\section{Universities of applied sciences (UAS)}


In Finland, universities that started their functions in 1996. UAS were developed into higher education institutions through merging vocational and higher postsecondary colleges and polytechnics. UAS offer professionally oriented higher education and have strong ties with working life and regional development. 